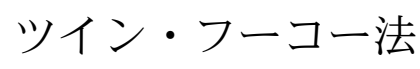

原田研*1

\title{
Twin-Foucault Imaging (TFI)
}

\author{
Ken HARADA*1 \\ ${ }^{* 1}$ Central Research Laboratory, Hitachi Ltd., Akanuma 2520, Hatoyama-machi, Saitama 350-0395, Japan
}

(Received April 28, 2014, Accepted July 21, 2014)

\begin{abstract}
A novel Lorentz electron microscopy - twin-Foucault imaging (TFI) method - is introduced. The twin-Foucault imaging method enables observation of two Foucault images simultaneously by using an electron biprism instead of an objective aperture. The electron biprism is installed between two electron beams deflected by magnetic domains. Potential applied to the biprism deflects the two electron beams further, and two Foucault images are then obtained in one visual field. The twin-Foucault images are able to extract the magnetic domain structures and to reconstruct an ordinary electron micrograph. The Foucault method was demonstrated with $180^{\circ}$ domain and $90^{\circ} / 180^{\circ}$ domain structures of manganite $\mathrm{La}_{1-\alpha} \mathrm{Sr}_{\alpha} \mathrm{MnO}_{3}$.
\end{abstract}

\section{1. はじめに}

Lorentz 顕微鏡法 ${ }^{1-4)}$ は, 透過型電子顕微鏡（Transmission Electron Microscope (TEM)) を用いた一般的な磁性 観察手法であり, 電子線が磁性体を透過する間に受けるロー レンツ (Lorentz) 力による偏向を可視化する点を特徵とし ている，さらに，今日では磁場による偏向にとどまらず，電 場による偏向も含め回折効果以外の偏向を可視化する手法と して発展しており, 走査型電子顕微鏡 (Scanning Electron Microscope (SEM)) を用いた反射法5), 走查透過型電子顕 微 鏡 ( Scanning Transmission Electron Microscope $(\mathrm{STEM})$ )を用いた位相差コントラスト法（Differential Phase Contrast (DPC) $)^{6)}$ など, 装置の特徵を活かした複数 の手法が開発されている. また, 干渉を利用して電子線の偏 向角度分布を位相分布として直接可視化できる電子線ホログ ラフィー7) や Coherent Foucault 法8)，そして，インフォー カス像と 2 枚のデフォーカス像から強度輸送方程式（Transport Intensity Equation (TIE)) に基づく画像処理によって 位相分布を求める方法 ${ }^{9}$ も, 磁性観察が可能な透過型電子顕 微鏡技法として発展している.

透過型電子顕微鏡を用いた磁性観察法には，(i) 比較的高 い倍率, 高い分解能で磁区, 磁壁が直接観察できる, (ii) 磁 性体中の欠陥, 不純物などが観察できる, (iii) 磁場変化, 温 度变化など外部環境の变化の影響を動的に観察できる, など の特徵がある.そして,これらの特徵を 1 つの装置で実現 できるところも特徵のひとつであり利点である. 本稿では, 筆者が開発に携わっているLorentz 法（特に Foucault 法） の一つであるッイン・フーコー法（Twin-Foucault Imaging $(\mathrm{TFI}))^{10)}$ について, その手法といくつかの応用結果に関し て紹介する.

\section{2. ローレンツ (Lorentz) 法}

\section{1 材料中の均一な電磁場による偏向}

運動する荷電粒子（電荷 : $q$, 速度 : $v$ ) が均一な電磁場

*1 日立製作所中央研究所（干350-0395 埼玉県鳩山町赤沼2520）
(電場 $: E$, 磁束密度 $: B$ ) から受ける力は Lorentz力 $F$ で あり，一般に式(1)で表わされる.

$$
F=q(E+v \times B)
$$

誘電体あるいは磁性体などの材料中を透過する間に電子が 受ける偏向作用も, 均一な電磁場中での荷電粒子の運動と同 様に取り扱うことが可能で, 誘電体中では電荷密度の差によ る電場の方向への放物線運動, 磁性体中では磁束の方向を軸 とした円運動と考えればよい，厚さ $t$ の試料中での電場や磁 束密度が均一であるとき, 電子線が受ける偏向角度（光軸々 平行に入射した電子線が試料を射出する際の光軸と成す角 度）の大きさは, 誘電体（偏向角度 : $\theta_{E}$ ) と磁性体（偏向角 度 : $\left.\theta_{B}\right)$ のそれぞれの場合を分けて記述すると式(2), 式(3) と表わされる. 但し, 偏向される方位は $\theta_{E}$ と $\theta_{B}$ とでは直交 している.

$$
\begin{aligned}
& \theta_{E}=\frac{e E t}{2 m_{e} v^{2}}=\frac{E t}{4 V_{0}} \\
& \theta_{B}=\frac{e B t}{m_{e} v}=\sqrt{\frac{e}{2 m_{e}}} \frac{B t}{\sqrt{V_{0}}}=\frac{e}{h} B \lambda t
\end{aligned}
$$

ここで $e$ は電子の素電荷, $h$ は Planck 定数, $m_{e}$ は電子の質 量, $V_{0}$ は電子線に与えられた加速電圧， $\lambda$ は電子線を波と 捉えたときの波長である.

式 (2), 式(3)より, 偏向角度は電磁場の大きさとそれが 影響する範囲 (ここでは膜厚 $t$ ) に依存しているだけでなく, 入射する電子線の加速電圧 $V_{0}$ にも依存していることがわか る. 加速電圧が増すほど試料透過中に電子線が受ける偏向角 度が小さくなる傾向は, 誘電体も磁性体も同じであるがその 程度は誘電体の方が大きい, 透過型電子顕微鏡では, 透過能 を大きくするとともに結像光学系の球面收差を小さく抑える ため, 加速電圧の高い電子線を用いる傾向がある. そのた め, 原理的には誘電体よりも磁性体の方が観察が容易である.

しかし, 磁性観察に際しては, 電子光学系で用いられる電 子レンズや偏向器などの光学機器が発生させる磁場が磁性材 料の磁気特性に影響を与えないよう配慮する必要がある. 具 
体的には，(1)静電型レンズを用いる2)，(2)対物レンズをオフ にする11)，(3)試料を空間磁場が十分に弱い位置に配置する (長焦点弱励磁レンズを用いる) ${ }^{12)}$, (4)磁気シールドレンズ を用いる13,14)，などの対策が採られている。これらの対策 は, いずれも観察時に試料を磁場に浸漬させない工夫であ り，透過型電子顕微鏡が得意とする高分解能観察と両立しな い装置構成を必要とする，そのため，磁性材料観察のために 特化した構成を持つ電子顕微鏡を Lorentz 顕微鏡と呼び，他 の装置と区別することが多い。このような磁性材料の磁気特 性に対する配慮が光学系に制約を与えるため, 原理的容易さ が技術的容易さには結びついていないのが現状である.

Fig. 1 は磁性材料中で電子線が偏向する様子を示した模 式図である。図中 $r$ は電子線が磁性材料中で行う円運動の回 転半径であり, 一般に荷電粒子線では, 粒子速度 $v$ が決まる と, $B r=$ Constant の関係が知られている，例えば，相対論 効果を考慮して, 加速電圧 $300 \mathrm{kV}$ の電子線の場合の值は $B r$ $=2.10 \times 10^{-3}(\mathrm{~Wb} / \mathrm{m}), 200 \mathrm{kV}$ の場合の值は $1.65 \times 10^{-3}$ $(\mathrm{Wb} / \mathrm{m})$ である.

Fig. 1 のモデルに基づき電子線の受ける偏向角度 $\theta_{B}$ を見 積ってみると, 例えば, 膜厚 $100 \mathrm{~nm}$ のコバルト $(\mathrm{Co})$ 薄膜 を加速電圧 $300 \mathrm{kV}$ の電子顕微鏡で観察する場合, $\theta_{B}=0.8 \times$ $10^{-4} \mathrm{rad}$ となり単純な結晶格子による Bragg 角よりも 2 桁 も小さい. このように, 試料を磁場中に浸漬させてはならな いという制約を受けた光学系において, 小さな偏向を受けた 電子線分布を如何に可視化するかが，透過型電子顕微鏡を用 いた磁性材料観察手法に共通する課題である. 以下に, 基本 となる 2 つの手法を紹介する.

\section{2 フレネル (Fresnel) 法}

Fig. 2 に Lorentz 法の 1 つである Fresnel 法で磁性材料を 観察する際の光学系と, 各々の光学系の下部に Fresnel 像を 例示する. $180^{\circ}$ 反転磁区構造を有する均一な厚さの磁性材 料を試料とし，平行入射した電子線が，図面上左右に同じ角 度ずつ偏向を受ける様子を示している．偏向を受けた電子線 は試料下方に十分な距離だけ伝播すると, 対物レンズの物面 （図中赤色の一点鎖線で示した）上に抏てて磁壁に該当する 位置で互いに重なりあう状況と, 逆に互いに離れる状況が発 生する.この対物レンズの物面上での電子線の強度の粗密を 結像するのが Fresnel 法である.この物面については, 試料 の下側（オーバーフォーカス条件）と上側（アンダーフォー

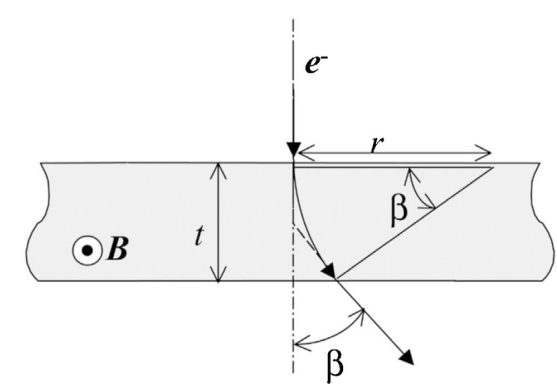

Fig. 1 Schematic drawing of electron beam deflection inside magnetic material.
カス条件）の両方の場合が, 光学系として構築可能である.

Fig. 2(a)はオーバーフォーカス（過焦点）条件, Fig. 2(b) はアンダーフォーカス（不足焦点）条件であり，対物レンズ の物面は, それぞれ試料の下側, 上側に位置する様, 光学系 が調整されている，試料に入射した電子線は，試料内部の磁 化により偏向を受け，ちょうど磁壁に沿って粗密が発生す る. その結果, 磁壁が明線 (白色) または暗線 (黒色) のコ ントラストで観察される. Fig. 2(a)，(b)に示すごとく，フ オーカスの過不足が逆転すると磁壁のコントラストも反転す る。また，磁壁を構成する磁区の極性にも依存してコントラ ストが反転する. Fresnel 像における磁壁のコントラストの 大きさは，フォーカスをはずす量（デフォーカス量）と電子 線が受ける偏向の大きさに依存し, 強磁性材料などで電子線 が大きく偏向される場合には数百 $\mathrm{nm}$ 程度の小さなデフォー カス量で十分なコントラストが得られるが，磁束量子など小 さな偏向しか与えない観察対象の場合には, 数百 $\mathrm{mm}$ もの デフォーカス量が必要となる場合もある17,18).

Fresnel 法は, 光学系のフォーカスをはずすだけでコント ラストが得られるため簡便で, 最も多用されている観察手法 である。例えば，試料材料と磁壁との相互作用の観察15)や 磁区の核生成16)など, 動的な観察にも有効である。また, 磁性材料以外にも, 例えば超伝導材料中の磁気構造（磁束量 子の空間分布）の動的観察17,18)などにも用いられている.

\section{3 フーコー (Foucault) 法}

Fig. 3 は, Foucault 法による磁区構造観察の光学系であ る. Fig. 2 と同様に均一な膜厚の $180^{\circ}$ 反転磁区構造を有する 試料を透過した電子線は，それぞれの磁区で互いに逆方向に 偏向を受け，対物レンズの後焦点面（厳密には光源の像面） で，偏向角度に応じた位置にクロスオーバー（光源の像）を 結ぶ. Foucault 法はこの位置に対物絞り（角度制限絞り） を挿入し, 観察したい磁区からの電子線のみを選択し結像さ せる方法である. 例えば Fig. 3(a)では, 紙面表向きの磁化 を持つ磁区を透過し紙面上右方向に偏向された電子線を選択 した例であり，Fig. 3(b)は逆に，紙面裏向きの磁化を持つ 磁区を透過し紙面上左方向に偏向された電子線を選択した例

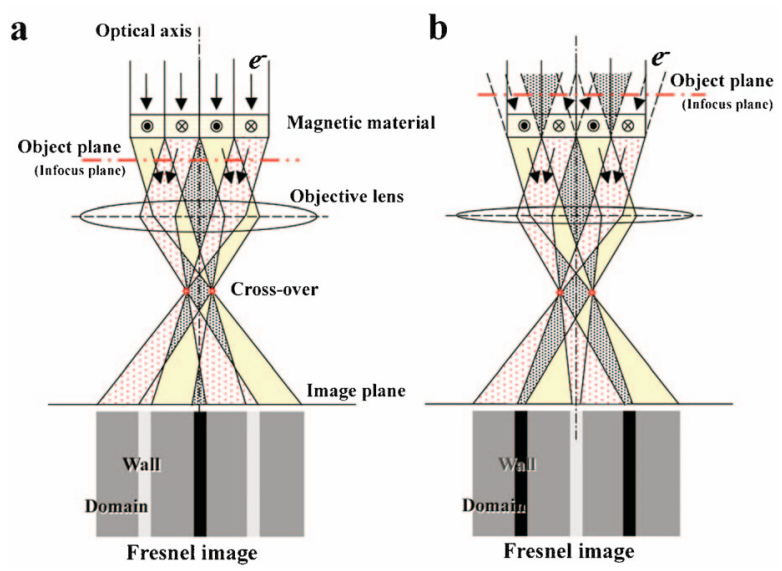

Fig. 2 Schematic diagrams of optical systems for Fresnel mode: (a) over-focus condition, (b) under-focus condition. 
である、いずれにしても，選択された磁区が明，選択されな かった磁区が暗(電子が来ない)のコントラストで観察され, Fig. 3 の場合, 磁区構造がストライプ状の Foucault 像とし て可視化される.

Foucault 法ではインフォーカスで試料像が観察されるた め高い分解能での観察が期待されるが，軸非対称な対物絞り の挿入法を用いた場合にはコントラストの成因には別途に検 討が必要となる，あるいは孔径の小さな対物絞りを使用した 場合には得られる空間分解能は回折収差により制限される. さらに Foucault 法でのコントラストの成因は，観察しない 磁区を透過した電子線の遮蔽によるものであり，『情報の一 部を捨てる』ことによって得られている。そのため，結晶粒 界など複数の磁区に渡った対象を観察する場合には，例え ば，対物絞りを調整し直して逆コントラストの Foucault 像 を観察するか，通常の電子顕微鏡像を観察しておくなど，複 数回の観察が必要であった。すなわち, 動的観察，実時間観

a

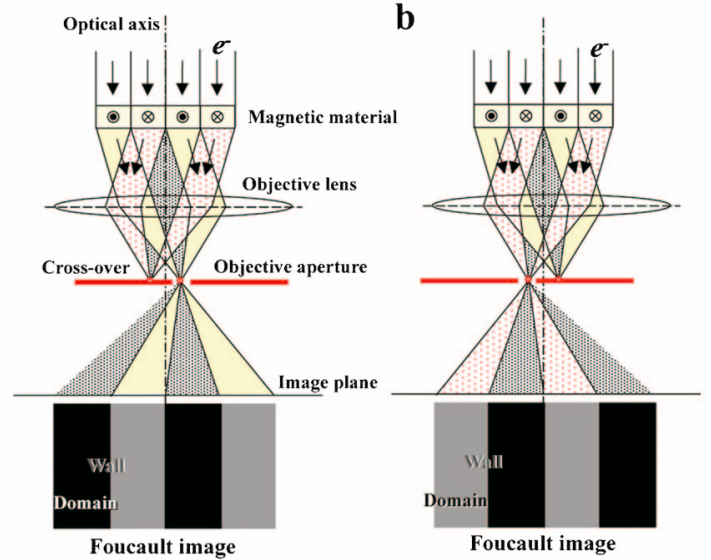

Fig. 3 Schematic diagrams of optical systems for Foucault mode, (a) imaging by deflected beam on right-side, (b) imaging by deflected beam on left-side.
察などはほぼ不可能であった。本稿で紹介する Twin-Foucault 法 ${ }^{10)}$ は，偏向された電子線の対物絞りによる取捨選択 ではなく，電子線バイプリズムを用いた偏向電子線の過偏 向, または不足偏向による分別結像法であり, 上記欠点の解 決手法の一つである.

\section{3. ツイン・フーコー法（Twin-Foucault Imag- ing (TFI))}

\subsection{Twin-Foucault 法の光学系}

Fig. 4 に Twin-Foucault 法の光学系を示す.図では簡略 化のため照射光学系, 拡大結像系は省略し, 光源, 試料, 対 物レンズ，電子線バイプリズム，像面からなる光学系を示し ている. 光源から放出された電子線は, 照射光学系により試 料への適切な電子密度, 照射範囲となるように調整される. 試料の所定の領域を照射した電子線は, 試料内の例えば反転 磁区構造などにより方位の異なる 2 方向に偏向され，対物 レンズの下側に 2 つ分離された光源の像（クロスオー バー）を結ぶ. 対物レンズによるクロスオーバーの近傍に配 された電子線バイプリズムにより電子線は改めて偏向を受 け，それぞれの偏向方向に応じた試料の像を個別に結ぶ。 Fig. $4(\mathrm{a})$ は電子線バイプリズムに負の電压を印加 $\left(V_{\mathrm{f}}<0 \mathrm{~V}\right)$ し, 両クロスオーバーからの電子線が互いに重ならないよう に偏向（不足偏向）している。一方，Fig. 4(c)は電子線バ イプリズムに正の電圧を印加（ $V_{\mathrm{f}}>0 \mathrm{~V} ）$ し，両クロスオー バーからの電子線が像面に伝播・結像するまでに交差を完了 する様に偏向（過偏向）を与えている．近軸近似の範囲内で は，Fig. 4(a) と Fig. 4(c)では，得られる 2 つ像の左右の 位置が入れ替わるだけで同じ結果を得る．Fig. 4(b) は，電 子線バイプリズムへの印加電圧をゼロとした場合 $\left(V_{\mathrm{f}}=0 \mathrm{~V}\right)$ で，通常の電子顕微鏡像を得ることができる. Fig. 4(b)の 構成によれば，電子線バイプリズムを挿入したまま，Fresnel 像の観察も可能である.

Fig. 4 では電子線バイプリズムが対物レンズの作り出す光

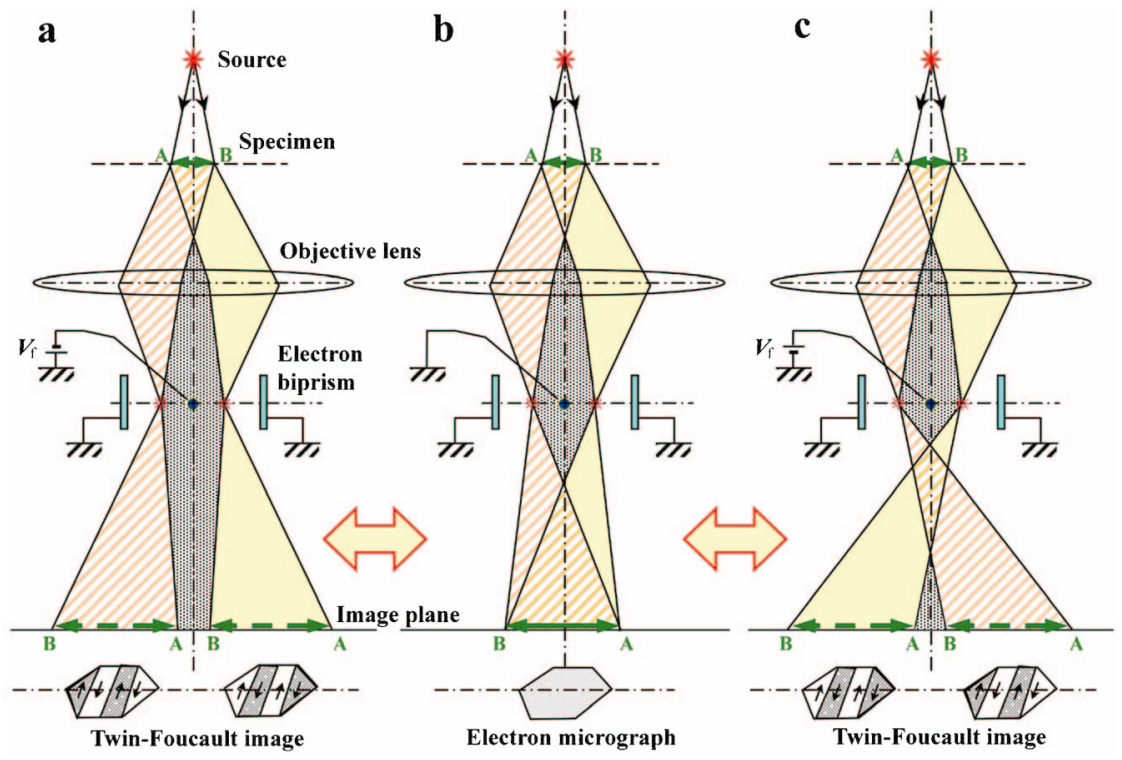

Fig. 4 Schematic diagrams of optical systems for twin-Foucault imaging: (a) $V_{\mathrm{f}}<0 \mathrm{~V}$, (b) $V_{\mathrm{f}}=0 \mathrm{~V}$, (c) $V_{\mathrm{f}}>0 \mathrm{~V}$. 


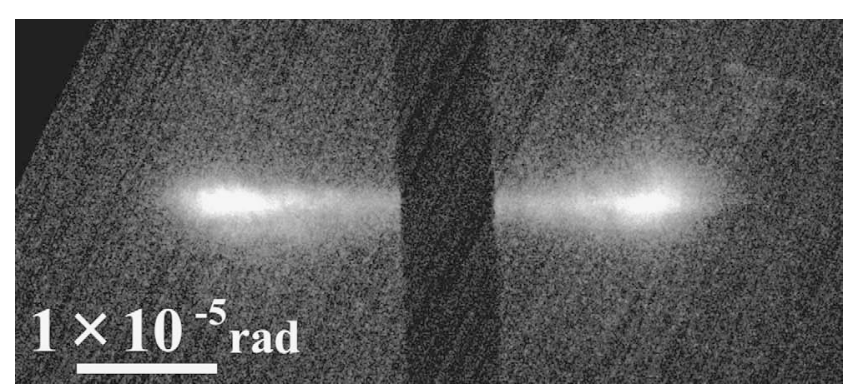

Fig. 5 Electron diffraction pattern of Bloch-type $180^{\circ}$ walls of manganite LSMO.

源の像面に配置された例を示している. 図中灰色のハッチン グ部分は電子線が通過しない陰の空間である. 電子線バイプ リズムの位置は, 両クロスオーバーの間の電子線の陰の空間 であれば，どこでも同様の結果を得ることができる，電子顕 微鏡の機械構成などを勘案して, 電子線バイプリズムの設置 位置を定狆ば良い。いずれの位置においても，機械的，空 間的に設置可能な電子顕微鏡の装置上のスペースがあること と, 電子線バイプリズムのフィラメント電極の太さが陰の空 間内に収まることが必要である。一般に，陰の空間サイズは 試料像の拡大とともに逆に縮小されていくので，例えば Fig. 4 に示したように，クロスオーバー近傍などが妥当と考 えられる.

Fig. 4 のように Twin-Foucault 法に抢ける電子線バイプリ ズムの利用は, 従来の電子線ホログラフィーなど干渉法とは 異なり，2 方向の電子線を空間的に分離させ， 2 つの像をそ れぞれ個別に結像する目的で使用されている。したがって, 本観察法は電子線の可干渉性に依存しない。

\subsection{Twin-Foucault 法の観察例 \\ 3.2.1 $180^{\circ}$ 反転磁区構造の観察}

Twin-Foucault 法を用いた応用例として，180 反転磁区構 造の観察結果を紹介する. 試料にはマンガン酸化物系の材料 $\mathrm{La}_{0.825} \mathrm{Sr}_{0.175} \mathrm{MnO}_{3}$ を用いた。本材料は $190 \mathrm{~K}$ 以下で常磁性 から強磁性へ相転移し, 強磁性相では $180^{\circ}$ 反転磁区構造を とることが知られている19).

Fig. 5 は $180^{\circ}$ 反転磁区構造の小角電子回折パターン

$(106$ K) である. CCD 記録時のカメラ長は $155 \mathrm{~m} て ゙$, 通常の Bragg 回折パターン観察時の $200 \sim 300$ 倍程度の拡大像に該 当する. Fig. 5 では回折（偏向）スポットがストリークを引 きながら 2 つに分離している様子がわかる。このストリー クは電子線の偏向が徐々に減少し, 光軸を経由して逆方向に 偏向していることを示しており, $180^{\circ}$ 反転磁区の磁壁部分 で磁化が膜面垂直の状態, すなわち電子線と平行な状態を取 る Bloch 型の磁壁であることを示している. 分離したスポ ット間の中央部の縦方向の黒い帯状のコントラストが, 挿入 された電子線バイプリズムのフィラメント電極の像である. 電子線が透過しないため, 黒いシルエットとなって観察され ている.

Fig. 6 は電子線バイプリズムのフィラメント電極への印
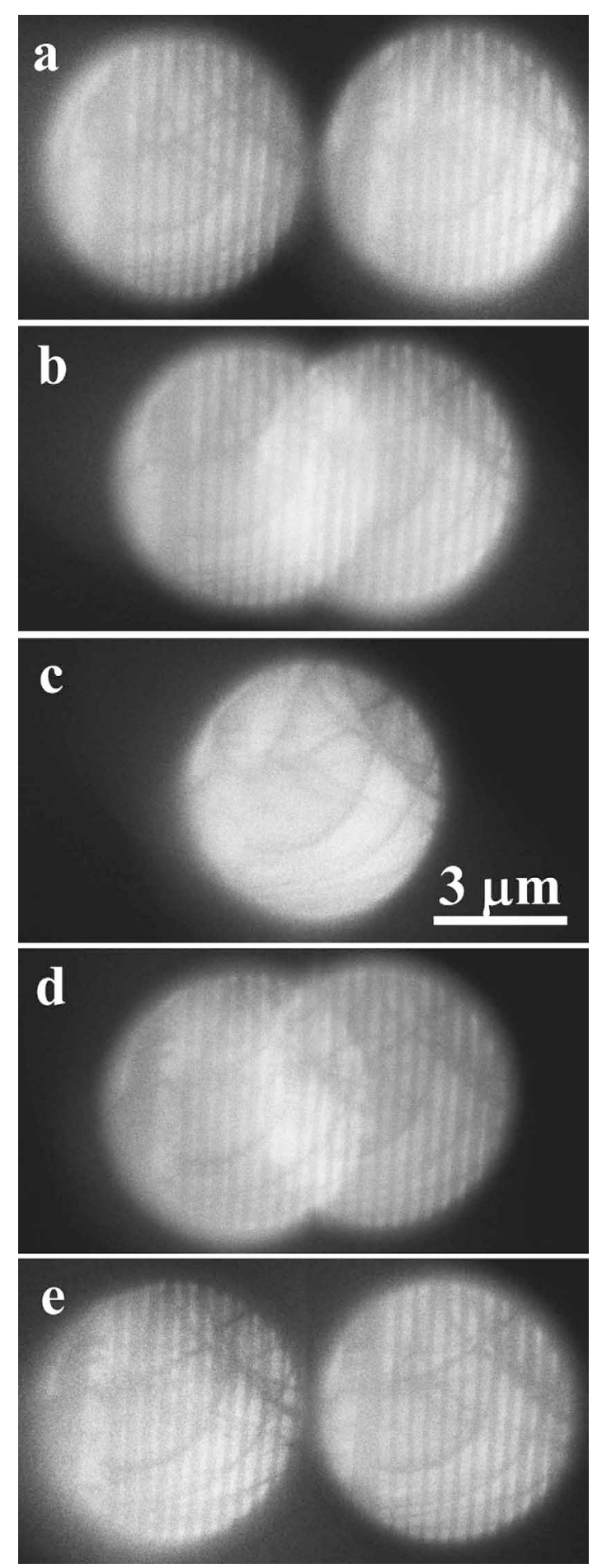

Fig. 6 Twin-Foucault images depending on the potentials $V_{f}$ applied on the electron biprism: (a) $V_{\mathrm{f}}=-100 \mathrm{~V}$, (b) -50 $\mathrm{V}$, (c) $0 \mathrm{~V}$, (d) $+50 \mathrm{~V}$, (e) $+100 \mathrm{~V}$.

加電圧を変化させたときに観察された試料の像である. カメ ラの撮像範囲内（すなわち視野中）に $2 つ の$ Foucault 像を 含めなければならないため, 観察範囲は従来の Foucault 法 よりも狭くしている，それぞれの印加電圧 $V_{\mathrm{f}}$ は，Fig. $6(\mathrm{a})$ $-100 \mathrm{~V}$, (b) $-50 \mathrm{~V}$, (c) $0 \mathrm{~V}$, (d) $+50 \mathrm{~V}$, (e) $+100 \mathrm{~V}$ であ る. Fig. 6(a)，(c)，(e)がそれぞれ Fig. 4(a)，(b)，(c)の光 学系に対応している. Fig. 6(a), (e)の左右の Foucault 像で は縦方向のストライプ状のコントラストが反転していること 
から，ストライプが磁区構造によるものであることがわか る. また, Fig. 6(c)より, 曲線状の縞模様が等傾角干渉縞 など試料固有のコントラストであることがわかる. Fig. 6 (c)の電子顕微鏡像が，フィラメント電極への電圧の印加に 伴って，それぞれの磁区を透過した電子線による Foucault 像に変化していく様子がわかる．2つの Foucault 像を分離 するために印加しなければならない電圧 $V_{\mathrm{f}}$ は観察領域の大 きさに依存しており, 観察したい領域が十分に分離されるだ けの電圧を印加できればよい，印加電圧が正負どちらの電圧 でもよいことは, Fig. 6(a) と (e)で, 左右の Foucault 像が 入れ替わっているだけであることから明らかである.

Fig. $6(\mathrm{a})$, (e)の左右の Foucault 像は, 全く同じ入射電子 線による全く同時結像の 2 枚の画像である. しかも, この 2 枚の Foucault 像で, 電子線の偏向に関しては試料の観察範 囲内の全情報を網羅できている。したがって従来のFoucault 法では困難であった, 複数の磁区構造の同時観察と動 的観察/実時間観察の両立が可能である.このように TwinFoucault 法では，1つの入射電子線により同時結像された異 なる情報を持った対画像を得ることができる. この 1 光束 2 画像は新しい概念である.

さらに，この条件を一にする 2 枚の画像を減算処理する ことによって, 差分像として磁区コントラストのみの抽出が 可能である. Fig. 7(a)，(b)はそれぞれ Fig. 6(a)の左右の Foucault 像である. この 2 枚の画像間の減算処理を行った. Fig. 7 (c)は Fig. 7 (a) から (b)を減算した画像（差分像）, Fig. 7(d)は Fig. 7(b) から (a) を減算した画像（差分像）で ある. 減算後の画像の強度ゼロが中間調となる様に全体の表 示の際の明るさを調整している. Fig. 7 (c) も (d) も, 試料が 固有に持つ欠陥や背景の等傾角干渉縞が除去され, 磁区によ

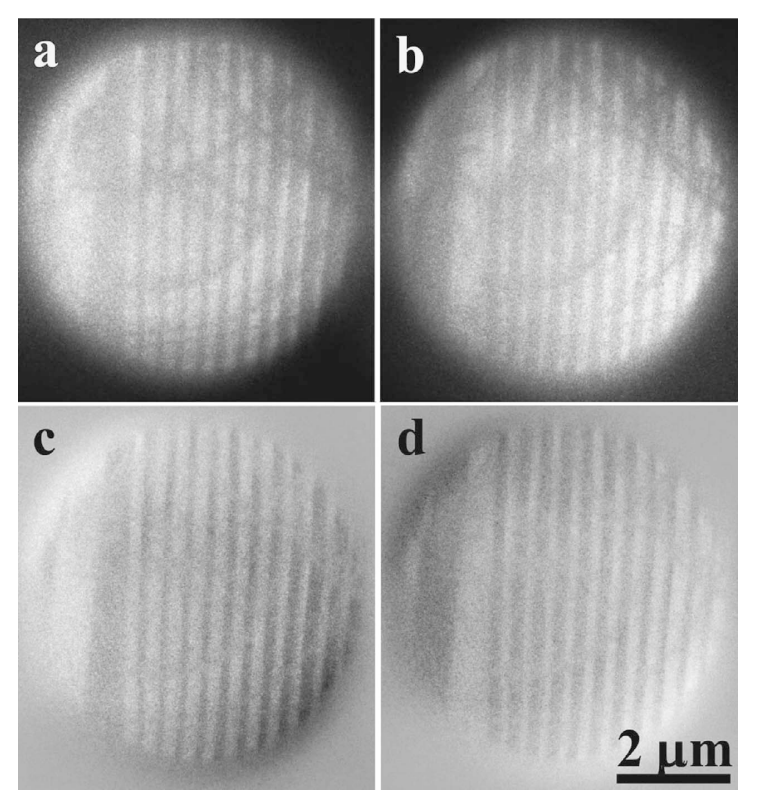

Fig. 7 Magnetic domain structures processed from twin-Foucault images: (a) twin-Foucault image of left-side of Fig. 6 (a), (b) right-side image of Fig. 6(a), (c) subtracted image ( (a) minus (b)), (d) subtracted image ((b) minus (a)).
るストライプ状のコントラストのみが強調された画像となっ ている. Fig. 7(c) と（d)とではコントラストが反転している こと, およびこれら一連の Foucault 像の元となった回折パ ターン（Fig. 5）より隣り合うストライプ構造が互いに逆向 きの磁化を持つ磁区であることがわかる．以上のように, Twin-Foucault 法では全く同一条件で記録された 2 枚の画像 に簡単な処理を施すだけで, 目的の磁区構造を低ノイズで高 精度に観察することが可能である.

本手法では, 差分像だけでなく合算像についても簡単な処 理が可能である. Fig. 8 に合算像についての試行結果を示 す. Fig. 8(a)は Fig. 6(c)の電子顕微鏡像，（b)は Fig. 6(a) の左右の Foucault 像の合算像 (Fig. 7(a), (b)の和) である.

Fig. 8(a)と (b) を比較すると, Foucault 像での磁区を表すス トライプ状のコントラストが消失し, 通常の電子顕微鏡像と ほぼ一致している。すなわち，本手法では Fig. 6(a) または (e)の Twin-Foucault 像を記録しておけば, 改めて電子顕微 鏡像を撮影する必要はない。これは全偏向方向の情報を得て いる利点によるもので, Twin-Foucault 法が同一性 ·同時性 だけでなく, 実験の効率化に於いて優れていることを示して いる.

なお，一般に偏向角度が小さい観察対象に対して Foucault 法が難しい点は Twin-Foucault 法でも同様である. 但 し, 電子線バイプリズムは制限視野絞りの位置に設置される ことが多く, 試料から電子線バイプリズムまでの距離を大き くとることが可能 22 であり, 例えば今回用いた光学系では 1 $\times 10^{-5} \mathrm{rad}$ 程度の偏向角度が得られれば, Twin-Foucault 法 は十分に実施可能である.

\subsection{2 $90^{\circ} / 180^{\circ}$ 磁区構造の観察}

Twin-Foucault 法の別の応用例として, $90^{\circ} / 180^{\circ}$ 磁区構造 の観察結果を紹介する. 試料は先と同種のマンガン酸化物 $\left.\left(\mathrm{La}_{0.75} \mathrm{Sr}_{0.25} \mathrm{MnO}_{3}(\mathrm{LSMO})\right)^{20}\right)$ である.この材料は, 室温で 磁性が発現されており, 結晶の双晶面が磁壁となることが知 られている。

Fig. 9 は，90\% $/ 180^{\circ}$ 磁区の Fresnel 像である. Fig. $9(\mathrm{a})$ がアンダーフォーカス (不足焦点) 像, (b)がオーバーフォー カス (過焦点) 像である. 各々の図中横方向の直線が $90^{\circ}$ 磁 壁であり, 図中央部のジグザグの縦線（（a）黒線，（b)白線） が $180^{\circ}$ 磁壁である. 図の中央部に上下に伸びる緩やかに曲 がった黒い帯状のコントラストは等傾角干渉縞であり,

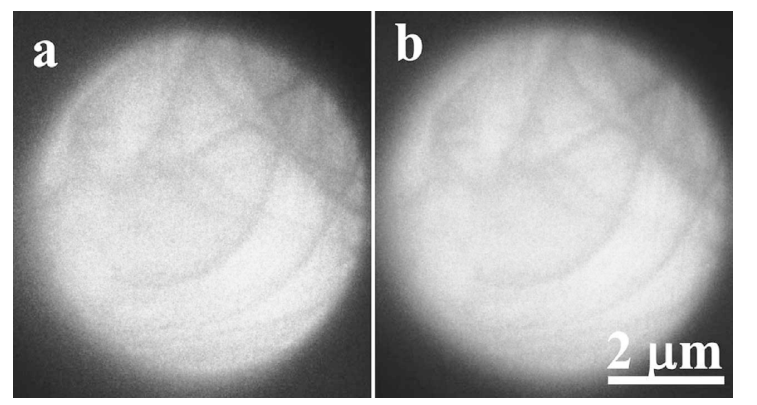

Fig. 8 (a) ordinary infocus image (Fig. 6(c)), (b) summed image (Fig. $7(\mathrm{a})+(\mathrm{b}))$. 
$90^{\circ}$ 磁壁で等傾角干渉縞がずれていることから, $90^{\circ}$ 磁壁と双 晶境界とが一致していることがわかる. 各々の磁区の磁化方 向は図中に矢印で示した，このようにFresnel 法では, 磁区 構造と結晶構造との関係を知ることが容易である.

Fig. 10に Twin-Foucault 像と小角電子回折パターン（挿 入図）を示す． $90^{\circ} / 180^{\circ}$ 磁区構造は, 互いに直交する 4 方 向の磁区から構成されるため, 小角電子回折パターンでは 4 つの偏向スポットが得られる. 光軸（回折パターンの中心） を挟んで縦のストリーク（上下のスポット間）が $90^{\circ}$ 磁壁, 光軸を通りクロスしている弱いストリークが $180^{\circ}$ 磁壁に対 応する小角回折パターンである.この回折パターンのスポッ 卜位置が正方形からわずかだけずれているが，これは結像レ ンズ系の残留歪によるものと推定している. また，回折パ ターンの左下スポットが強く励起されているが，これは入射 電子線と試料の結晶方位の関係によるものではないかと推定 しているが，詳細は検討中である.
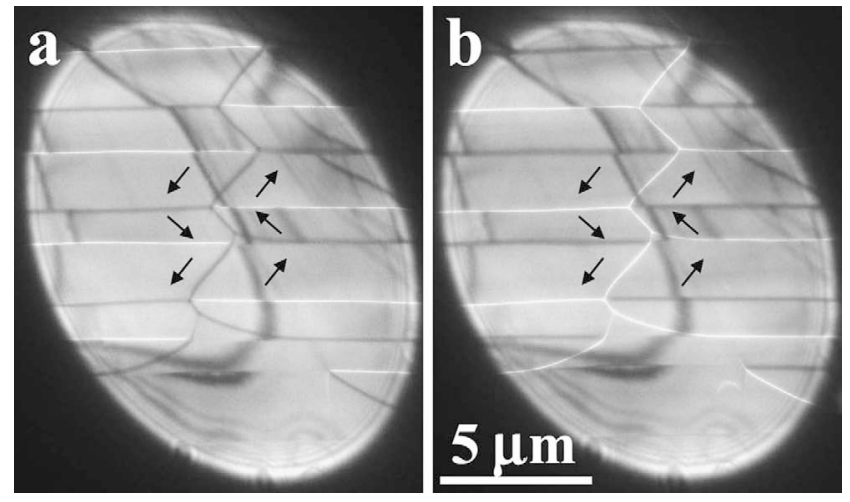

Fig. 9 Fresnel images of $90^{\circ} / 180^{\circ}$ domain structure of LSMO: (a) under-focus, (b) over-focus. $90^{\circ} / 180^{\circ}$ 磁区構造は, 基本的に 4 つのスポットから成る 回折パターンであるため, 電子線バイプリズムのフィラメン 卜電極の挿入方向・挿入位置にも複数通りの組み合わせが可 能となる.さらに，2つの電子線バイプリズムを用いること により，原理的に 4 スポットまで個別に分離観察可能であ ることを確認している.

Fig. 10 (a)の挿入図は, $90^{\circ}$ 磁壁ごとにコントラストが反 転する様に, 電子線バイプリズムのフィラメント電極を挿入 した回折パターンである. 図中水平方向にある黒い帯状のコ ントラスト（白矢印にて強調した）が，フィラメント電極の 像である. Fig. 10(a)は, フィラメント電極に-200 V の電 位を印加した時の Twin-Foucault 像である. 回折パターン (挿入図) や Fresnel 像（Fig. 9）から得られた情報ととも に, 観察部位は, 4 つ $90^{\circ}$ 磁区から成る構造であり, 各々 の磁区が交互に異なるコントラストを持って観察されている.

Fig. 10 (b)の挿入図は回折パターン中の 4 つスポットのう ち一つだけを抽出する様に, フィラメント電極を光軸を軸に 約 $75^{\circ}$ 回転させて挿入した際の回折パターンである. 1 つの スポットを分離する関係上, 電子線バイプリズムは光軸から 少しずらして挿入されている. Fig. 10 (b)は, フィラメント 電極への印加電圧 $-140 \mathrm{~V}$ の時の Twin-Foucault 像である. 右上の Foucault 像は, 該当する 1 つ磁区の久を観察でき ている. 左下の Foucault 像は，3つの磁区から構成される ため, Fig. 10(b)では若干のアンダーフォーカスを与えて, 3 つの磁区内の磁壁を可視化している.

以上の様に, Twin-Foucault 法では, 全く同一の入射条件 で同時に 2 枚の Foucault 像が得られていること, 孔径の小 さな対物絞りを用いないため比較的高い空間分解能で磁区を 観察できていること, 磁区コントラストのみを可視化できる こと, 電子線バイプリズムへの印加電圧のコントロールだけ

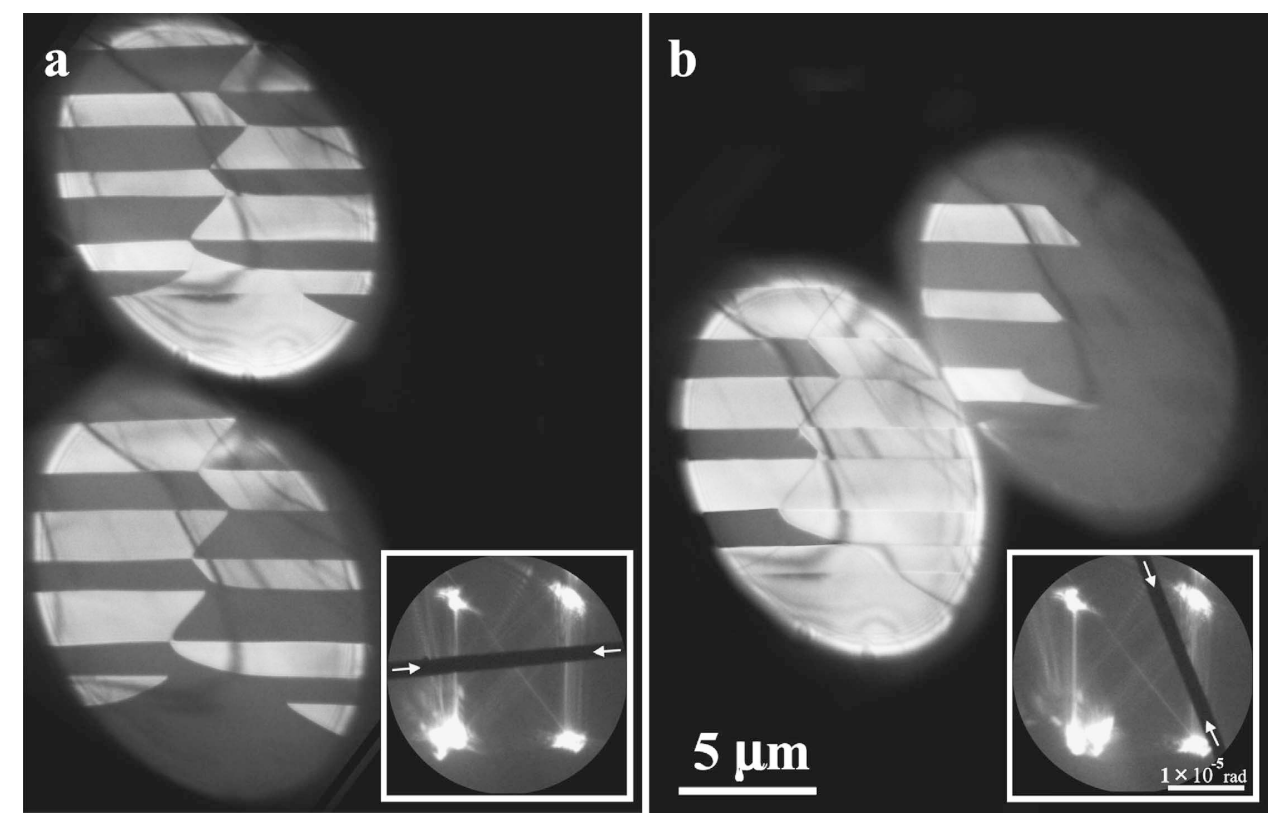

Fig. 10 Twin-Foucault images of $90^{\circ} / 180^{\circ}$ domain structure of LSMO: (a) split images from each two $90^{\circ}$ domains, (b) single domain image split from other three $90^{\circ}$ domains. 
で光学系を修正することなく, Foucault 像と通常の電子顕 微鏡像を得られること, Fresnel 法にも適用できることな ぞ，従来の Lorentz 顕微鏡法には無い利点を有している.

\section{4. おわりに}

Lorentz 顕微鏡法に代表される透過型電子顕微鏡を用いた 磁性観察法は，一般的には古い技術と考えられている. しか し, 小角回折法が再び見直されていること裤や, Foucault 法の一つである Lens-less Foucault 法 ${ }^{22)}$ や電子線ホログラフ ィーにも新しい観察手法が開発されている23,24)こと, そして 急速に発展している走査透過型電子顕微鏡に関する技術（特 に検出器関連技術）には磁性観察法への展開が可能なものが 少なくないことなど，透過型電子顕微鏡を用いた磁性観察法 にも新しい展開が芽生え始めている。一般に新しい技術は, 観察対象や観察手法に新しい世界を拓いてくれる. 今後, Lorentz 法にも飛躍的な技術進歩が期待される.

\section{謝辞}

本研究で使用したマンガン系酸化物（LSMO）試料は，大 阪府立大学の森茂生先生にご提供いただきました。感謝申し 上げます。また，ここで用いた画像処理に関しては，日立製 作所中央研究所の高口雅成氏，常田るり子氏，実験装置に関 しては，同じく日立製作所中央研究所の葛西裕人氏，池田正 樹氏にご協力いただきました．ここに記して謝意を表します.

\section{〔文献〕}

1) M. E. Hale, H. W. Fuller and H. Rubinstein: J. Appl. Phys., 30 (1959) 789.

2) H. W. Fuller and M. E. Hale: J. Appl. Phys., 31 (1960) 1699.

3) J. N. Chapman: J. Phys. D: Appl. Phys., 17 (1984) 623.

4) K. Harada: Electron Microscopy, 35 (2000) 62 [in Japanese].
5) T. Ikuta and R. Shimizu: Phys. Stat. Sol., 23 (1974) 605.

6) J. N. Chapman, P. E. Batson, E. M. Waddell and R. P. Ferrier: Ultramicroscopy, 3 (1978) 203.

7) A. Tonomura: Electron Holography, 2nd ed. (Springer, Heidelberg, Germany, 1999).

8) J. N. Chapman, A. B. Johnston and L. J. Heyderman: J. Appl. Phys., 76 (1994) 5349.

9) K. Ishizuka and B. Allman: J. Electron Microsc., 54 (2005) 191.

10) K. Harada: Appl. Phys. Lett., 100 (2012) 061901.

11) T. Matsuda, S. Hasegawa, M. Igarashi, T. Kobayashi, M. Naito, H. Kajiyama, J. Endo, N. Osakabe, A. Tonomura and R. Aoki: Phys. Rev. Lett., 62 (1989) 2519.

12) J. Dooly and M. De Graef: Ultramicroscopy, 67 (1997) 113.

13) K. Shirota, A. Yonezawa, K. Shibatomi and T. Yanaka: J. Electron Microsc., 25 (1976) 303.

14) T. Hirayama, Q. Ru, T. Tanji and A. Tonomura: Appl. Phys. Lett., 63 (1993) 418.

15) Y. Murakami, D. Shindo, K. Kobayashi, K. Oikawa, R. Kainuma and K. Ishida: Mater. Sci. Eng., 438-440 (2006) 1050.

16) Y. Murakami, H. Kasai, J. J. Kim, S. Mamishin, D. Shindo, S. Mori and A. Tonomura: Nature Nanotech., 5 (2010) 37.

17) K. Harada, T. Matsuda, J. E. Bonevich, M. Igarashi, S. Kondo, G. Pozzi, U. Kawabe and A. Tonomura: Nature, 360 (1992) 51.

18) K. Harada: Microscopy, 62 (2013) S03.

19) S. Mori, T. Asaka and Y. Matsui: Electron Microscopy, 37 (2002) 56 [in Japanese].

20) S. Mori, T. Asaka, Y. Horibe, Y. Matsui and K. Takenaka: J. Electron Microsc., 54 (2005) i65.

21) K. Takayanagi, T. Koyama, S. Mori, K. Harada and Y. Togawa: J. Electron Microsc., 61 (2012) 401.

22) Y. Taniguchi, H. Matsumoto and K. Harada: Appl. Phys. Lett., 101 (2012) 093101.

23) T. Tanigaki, S. Aizawa, H. S. Park, T. Matsuda, K. Harada and D. Shindo: Ultramicroscopy, 137 (2014) 7.

24) R. Tsuneta, H. Kashima, K. Harada, T. Iwane, M. Ikeda, A. Sugawara and M. Koguchi: Kenbikyo, 48 (2013) 205 [in Japanese]. 